\title{
Aktivitas Kombinasi Infusa Daun Sirih Merah dan Infusa Daun Sirih dengan Klorheksidin terhadap Pertumbuhan Porphyromonas gingivalis
}

\author{
Casanti Wiji Rahayu, Raden Muhamad Hovi Nurakbar, Yustina Sri Hartini*
}

Fakultas Farmasi Universitas Sanata Dharma, Kampus III Paingan Maguwoharjo Depok Sleman Yogyakarta 55281

*Email korespondensi: yustinahartini@usd.ac.id

(Submit 15/03/2019, Revisi 05/09/2019, Diterima 20/12/2019)

\begin{abstract}
Abstrak
Penggunaan klorheksidin secara terus menerus merupakan salah satu penyebab terjadinya resistensi bakteri Gram negatif anaerob Porphyromonas gingivalis. Kombinasi klorheksidin dengan bahan alam yang memiliki khasiat antibakteri diharapkan menghasilkan efek sinergi yang dapat mengatasi resistensi bakteri $P$. gingivalis. Penelitian ini mengukur aktivitas antibakteri kombinasi infusa daun sirih merah (Piper crocatum Ruiz \& Pav./Pc) dan infusa daun sirih (Piper betle L./Pb) dengan klorheksidin terhadap $P$. gingivalis, diharapkan terjadi efek sinergi pada kombinasi bahan antibakteri tersebut. Penelitian ini bertujuan membandingkan aktivitas antibakteri kombinasi $\mathrm{Pc}$ dan $\mathrm{Pb}$ dengan klorheksidin terhadap $\mathrm{P}$. gingivalis terhadap bahan tunggalnya. Daun sirih merah dan daun sirih didapat dari daerah Sleman Yogyakarta. Ekstraksi senyawa dari daun sirih merah dan daun sirih dilakukan secara infundasi. Pengujian aktivitas antibakteri dilakukan dengan metode difusi sumuran menggunakan media nutrien agar darah. Penetapan aktivitas antibakteri bahan uji dengan pengukuran diameter zona hambat pertumbuhan $P$. gingivalis. Diameter zona hambat klorheksidin terhadap pertumbuhan $P$. gingivalis sebesar 2,36 $\pm 0,05 \mathrm{~cm}$. Kombinasi Pc 100\%; Pc 50\%; Pb 100\%; dan Pb 50\% dengan klorheksidin menghasilkan diameter zona hambat pertumbuhan $P$. gingivalis berturut-turut sebesar 2,0 $\pm 0 \mathrm{~cm} ; 1,93 \pm 0,01 \mathrm{~cm} ; 2,1 \pm 0 \mathrm{~cm}$; dan 2,18 $\pm 0,01 \mathrm{~cm}$. Kombinasi klorheksidin dengan Pc maupun dengan $\mathrm{Pb}$ tidak menghasilkan efek antibakteri yang lebih kuat terhadap pertumbuhan $P$. gingivalis, dibandingkan klorheksidin tunggal. Kombinasi klorheksidin dengan $\mathrm{Pc}$ maupun $\mathrm{Pb}$ tidak menunjukkan efek sinergi. Pemanfaatan Pc maupun $\mathrm{Pb}$ sebagai antibakteri tidak direkomendasikan untuk dikombinasi dengan klorheksidin.
\end{abstract}

Kata kunci: Kombinasi, Piper crocatum Ruiz \& Pav., Piper betle L., Klorheksidin, Porphyromonas gingivalis

\section{Outline}

- Pendahuluan

- Metode

- Hasil dan Pembahasan

- Kesimpulan

- Ucapan Terima Kasih

- Daftar Pustaka 


\section{Pendahuluan}

Porphyromonas gingivalis ( $P$. gingivalis) merupakan bakteri anaerob Gram negatif yang menyebabkan hampir $82 \%$ dari kasus periodontitis, dengan gejala peradagangan dan kerusakan jaringan ${ }^{1}$. Klorheksidin merupakan antibiotik yang digunakan untuk pengobatan periodontitis, namun ditemukan permasalahan resistensi bakteri bila antibiotik digunakan terus menerus ${ }^{2}$. Resistensi mikroorganisme terhadap antibiotik berdampak pada biaya pengobatan tinggi, infeksi kini kembali menjadi masalah di dunia pengobatan. Upaya pengatasan resistensi tersebut, dilakukan dengan pencarian senyawa baru atau kombinasi senyawa.

Sejak dahulu hingga kini praktik pengobatan dengan memanfaatkan bahan dari alam telah dihidupi oleh masyarakat Indonesia. Hampir semua senyawa obat sintetik jua berasal dari tanaman. Daun sirih merah (Piper crocatum Ruiz \& Pav./Pc) dan daun sirih (Piper betle L./Pb) telah digunakan sebagai obat tradisional untuk beberapa kasus infeksi. Aktivitas terhadap bakteri Gram positif dan Gram negatif dari Pc juga telah dilaporkan ${ }^{3}$. Kandungan karvakrol $\mathrm{Pb}$ bermanfaat sebagai desinfektan dan antijamur sehingga dapat dimanfaatkan untuk obat kumur dan keputihan ${ }^{6}$. Beberapa hasil penelitian menunjukkan bahwa senyawa bahan alam dapat meningkatkan aktivitas antibakteri dari antibiotik. Efek sinergi dari bahan antibakteri diharapkan mampu menghasilkan aktivitas antibakteri yang cukup kuat untuk mengatasi masalah resistensi bakteri. Penelitian ini membandingkan aktivitas antibakteri kombinasi infusa Pc maupun $\mathrm{Pb}$ dengan klorheksidin terhadap aktivitas masing-masing bahan pada pertumbuhan $P$. gingivalis.

\section{Metode}

Daun sirih merah dan daun sirih dikumpulkan dari daerah Ngemplak Sleman Yogyakarta. Determinasi kebenaran spesies tanaman dilakukan di Fakultas Biologi, Laboratorium Sistematika Tumbuhan, Universitas Gadjah Mada. Bakteri P. gingivalis diperoleh dari dan diidentifikasi pada Laboratorium Pengujian dan Kaliberasi Balai Laboratorium Kesehatan Yogyakarta. Bahan lain berupa akuades, alkohol 70\%, Nutrient Agar (NA) merk oxoid yang ditambahkan 10\% darah steril kambing, klorheksidin gluconate $0,2 \%$.

Ekstraksi senyawa dari daun sirih merah dilakukan dengan metode infundasi. Simplisia ( $P c$ dan $\mathrm{Pb}$ ) ditimbang sebanyak 50 gram untuk konsentrasi $100 \%$, kemudian dimasukan kedalam panci enamel dan ditambahkan akuades $50 \mathrm{~mL}$ dan untuk penjenuhan ditambahkan akuades sebanyak $100 \mathrm{~mL}$ ( 2 kali bobot). Selanjutnya dipanaskan diatas penangas air selama 15 menit terhitung dari suhu sudah mencapai $90 \mathrm{oC}$ sambil sesekali diaduk. Diserkai selagi panas melalui kain flannel, ditambahkan akuades secukupnya melalui ampas hingga diperoleh $20 \mathrm{~mL}$ infusa $\mathrm{Pc}$ maupun $\mathrm{Pb} 4$. Dibuat kombinasi infusa Pc dan infusa $\mathrm{Pb}$ konsentrasi $100 \%$ dan $50 \%$, dengan klorheksidin $0,2 \%$ dengan mengambil masing-masing $5 \mathrm{~mL}$ infusa $\mathrm{Pc}$ maupun $\mathrm{Pb}$ dan klorheksidin $0,2 \%$, dimasukan ke dalam labu ukur 10, digojog hingga homogen, sehingga diperoleh $10 \mathrm{~mL}$ kombinasi $\mathrm{Pc}$ dengan klorheksidin $0,2 \%$ dan kombinasi $\mathrm{Pb}$ dengan klorheksidin $0,2 \%$ dengan perbandingan $1: 1(\mathrm{v} / \mathrm{v})$. Pengujian aktivitas 
antibakteri dari $\mathrm{Pc}, \mathrm{Pb}$, dan klorheksidin tunggal, dilakukan dengan metode difusi sumuran untuk menetapkan diameter zona hambat pertumbuhan $P$. gingivalis.

\section{Hasil dan Pembahasan}

Determinasi tanaman menunjukkan tanaman yang digunakan adalah Piper crocatum Ruiz \& Pav dan Piper betel L., dan bakteri uji yang digunakan adalah Porphyromonas gingivalis. Media NA darah kontrol yang diinkubasi tampak bening dan tidak tampak kekeruhan, menunjukkan bahwa tidak terjadi kontaminasi mikroba pada media pertumbuhan bakteri uji (Gambar 1a). Pengujian pertumbuhan $P$. gingivalis pada media yang digunakan menunjukkan bahwa bakteri uji tumbuh baik (Gambar 1b). Hasil uji aktivitas antibakteri infusa $\mathrm{Pc}$ maupun infusa $\mathrm{Pb}$ konsentrasi $100 \%$ dan $50 \%$ disajikan pada Gambar 1c dan 1e, sedangkan kombinasi infusa Pc dengan klorheksidin serta kombinasi infusa $\mathrm{Pb}$ dengan klorheksidin disajikan pada Gambar 1d dan $1 \mathrm{f}$.

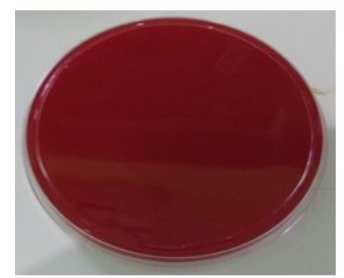

(a)

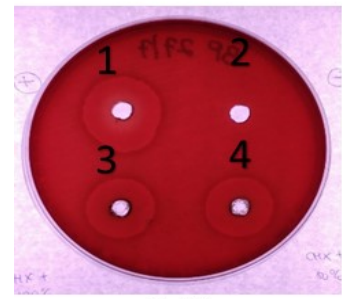

(d)

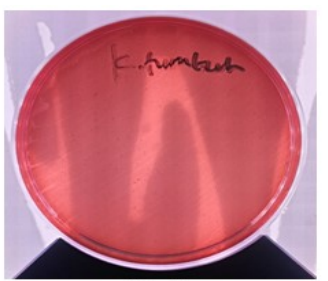

(b)

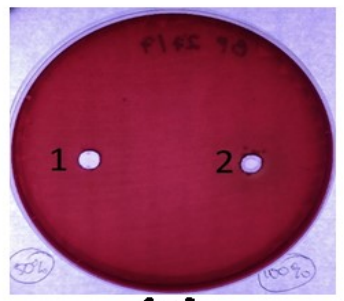

(e)

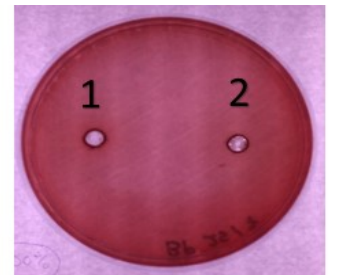

(c)

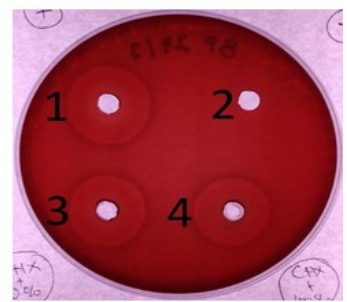

(f)

Gambar 1. Hasil pengujian aktivitas antibakteri (a) Media nutrient agar darah; (b) Pertumbuhan $P$. gingivalis pada media nutrient agar darah; (c) Uji aktivitas infusa Pc $100 \%$ (1) dan infusa Pc 50\% (2) terhadap P. gingivalis; (d) Uji aktivitas $P c$ terhadap $P$. gingivalis $1=$ klorheksidin $0,2 \%, 2=$ aguadest, $3=$ klorheksidin 0,2\%:Pc 100\%, 4 = klorheksidin 0,2\% :Pc 50\%; (e) Uji aktivitas infusa $\mathrm{Pb} 100 \%$ (1) dan infusa $\mathrm{Pb} 50 \%$ (2) terhadap $P$. gingivalis; dan (f) $\mathrm{Uji}$ aktivitas $\mathrm{Pb}$ terhadap $P$. gingivalis $1=$ klorheksidin $0,2 \%, 2=$ aguadest, $3=$ klorheksidin 0,2\% :Pb 100\%, 4 = klorheksidin 0,2\% :Pb 50\%.

Hasil uji dengan metode difusi sumuran menunjukkan bahwa klorheksidin 0,2\% menghasilkan diameter zona hambat sebesar 2,36 $\pm 0,05 \mathrm{~cm}$, sedangkan aquadest, infusa $\mathrm{Pc}$, dan infusa $\mathrm{Pb}$ pada konsentrasi $100 \%$ dan $50 \%$, tidak menghasilkan zona hambat terhadap pertumbuhan $P$. gingivalis. Khasiat antimikroba pada tanaman bergantung pada struktur kimia komponen aktif dan konsentrasinya. Ada berbagai komponen kimia pada tanaman sebagai antimikroba antara lain senyawa fenolik seperti terpen, alkohol alifatik, aldehid, keton, dan isoflavonoid. Sedangkan yang ditemukan di daun adalah senyawa saponin dan flavonoid ${ }^{5}$. Berdasarkan uji fitokimia yang dilakukan, 
sirih merah mengandung senyawa glikosida, triterpenoid/steroid, flavonoid, tanin, dan anthrakuinon. Infusa $\mathrm{Pc}$ dan $\mathrm{Pb}$ menghambat pertumbuhan dengan tingkat aktivitas yang sama terhadap pertumbuhan $S$. aureus, S. epidermidis, dan E. coli ${ }^{7}$. Hasil penelitian ini menunjukkan bahwa infusa $\mathrm{Pc}$ maupun $\mathrm{Pb}$ tidak memiliki aktivitas penghambatan pertumbuhan $P$. gingivalis.

Kombinasi campuran senyawa dapat diklasifikasikan menjadi sinergisme, antagonis, dan aditif. Antagonis adalah ketika kombinasi campuran senyawa menghasilkan efek yang lebih rendah dari senyawa individu atau tunggalnya ${ }^{8}$. Beberapa bahan alam menunjukkan efek sinergi ketika dikombinasi dengan antibiotic, kombinasi bahan ini baik untuk diteliti lebih lanjut. Kombinasi infusa $\mathrm{Pc}$ dan $\mathrm{Pb}$ dengan klorheksidin tidak menunjukkan peningkatan aktivitas antibakteri yang bermakna, justru terjadi penurunan luas zona hambat pertumbuhan bakteri $P$. gingivalis. Tidak terjadi efek sinergi pada kombinasi kedua bahan antibakteri tersebut, maka penelitian lanjutan tentang kombinasi bahan ini tidak direkomendasi.

\section{Kesimpulan}

Kombinasi klorheksidin dengan $\mathrm{Pc}$ maupun dengan $\mathrm{Pb}$ tidak menghasilkan efek antibakteri yang lebih kuat terhadap pertumbuhan $P$. gingivalis, dibandingkan klorheksidin tunggal. Kombinasi klorheksidin dengan $\mathrm{Pc}$ maupun $\mathrm{Pb}$ tidak menunjukkan efek sinergi. Pemanfaatan $\mathrm{Pc}$ maupun $\mathrm{Pb}$ sebagai antibakteri tidak direkomendasikan untuk dikombinasi dengan klorheksidin. Pemakaian $\mathrm{Pc}$ maupun $\mathrm{Pb}$ sebagai antibakteri tidak direkomendasikan untuk dikombinasi dengan klorheksidin.

\section{Ucapan Terima Kasih}

Terima kasih kepada Laboratorium Balai Kesehatan Yogyakarta yang telah mendukung pelaksanaan penelitian ini.

\section{Daftar Pustaka}

1. Hussain, $M$ et al, 2015, P. gingivalis in Periodontal Disease and AtherosclerosisScenes of Action for Antimicrobial Peptides and Complement, Frontiers in Immunology.

2. Kulik, E.M., Waltimo, T., Weiger, R., Schweizer, I., Lenkeit, K., Jenny, E.F, 2014. Development of Resitance of Mutans Streptococci and Porphyromonas gingivalis to Chlorhexidine Digluconat and Amine Flouride/Stannous Flouride - Containing Moutrinses, In Vitro, Clin Oral Invest, 1-6.

3. Farida et al., 2016

4. Badan Pengawas Obat dan Makanan RI, 2011, Acuan Sediaan Herbal, Badan Pengawas Obat dan Makanan RI, 1 (5), 3.

5. Hayek, S.A., et al., 2013, Antimicrobial Natural Products, Formatex Food Microbiology and Biotechnology Laboratory.

6. Nurmalina, R., 2012, 24 Herbal Legendaris untuk Kesehatan Anda, PT Elex Media Komputindo, Jakarta, 291-292. 
7. Hartini YS, Diaseptama YMS, Putri RN, Susanti LE, 2018, A Antagonistic Antibacterial Effect of Betel and Red Betel Combination against Gram-positive and Gram-negative Bacteria, In. J. Curr. Microbiol.App.Sci 7(5):267-272.

8. Bulusu, K.C., Guha, R., Mason, D.J., Lewis, R.P.I., Muratov, E., Motamedi, Y.K., Cokol, M., and Bender, A., 2016, An Overview of State of The Art in Predictive Modelling of Compound Combination Activity and The Value and Significance of Systems Informatics in Identifying Combinations for Therapeutic Purposes, vol. 21 (2), Elsevier Ltd., USA, 226. 